\title{
Hemodynamic changes in lipid emulsion therapy (SMOFlipid) for bupivacaine toxicity in swines $^{1}$
}

\author{
Alterações hemodinâmicas na terapia por emulsão lipídica (SMOFlipid) na intoxicação por \\ bupivacaína em suínos
}

\begin{abstract}
Marcos De Simone Melo ${ }^{\mathrm{I}}$, Matheus Rodrigues Bonfim ${ }^{\mathrm{II}}$, Elisabeth Dreyer ${ }^{\mathrm{III}}$, Betina Silvia Beozzo Bassanezi ${ }^{\mathrm{IV}}$, Artur Udelsmann ${ }^{\mathrm{V}}$
IFellow PhD degree, Anesthesiologist, Surgery Sciences Postgraduate Program, Department of Surgery, School of Medicine, UNICAMP, Campinas$\mathrm{SP}$, Brazil. The article is part of $\mathrm{PhD}$ thesis. Responsible for conception, design, acquisition and interpretation of data, manuscript writing.

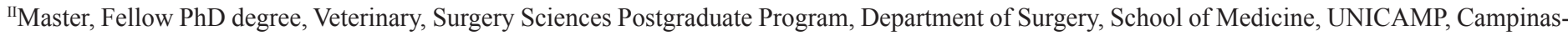
SP, Brazil. Acquisition of data and technical procedures.

IIIMaster, urse, Nutritional Support Team of the Hospital, UNICAMP, Campinas-SP, Brazil. Advisor and critical revision.

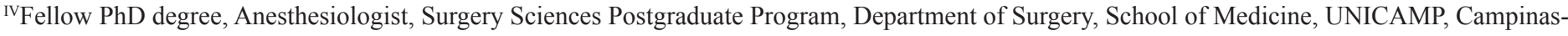
SP, Brazil. Conception and design.

vAssociate Professor, Department of Anesthesiology and Laboratory of Experimental Anesthesia, UNICAMP, Campinas-SP, Brazil. Conception, design, intellectual and scientific content, statistical analysis, manuscript writing.
\end{abstract}

\section{ABSTRACT}

PURPOSE: To evaluate the hemodynamic changes following SMOFlipid emulsion therapy with after bupivacaine intoxication in swines.

METHODS: Large White pigs were anesthetized with thiopental, tracheal intubation was performed and mechanical ventilation was instituted. Hemodynamic variables were recorded with invasive pressure monitoring and pulmonary artery catheterization (Swan-Ganz catheter). After a 30-minute resting period, $5 \mathrm{mg} \cdot \mathrm{kg}^{-1}$ of bupivacaine by intravenous injection was administered and new hemodynamic measures were performed 1 minute later; the animals were than randomly divided into two groups and received 4 ml.kg-1 of saline solution or $4 \mathrm{ml} . \mathrm{kg}^{-1}$ of SMOFlipid emulsion 20\%. Hemodynamic changes were then re-evaluated at 5, 10, 15, 20 and 30 minutes.

RESULTS: Bupivacaine intoxication caused fall in arterial blood pressure, cardiac index, ventricular systolic work index mainly and no important changes in vascular resistances. SMOFlipid emulsion therapy was able to improve blood pressure mainly by increasing vascular resistance since the cardiac index had no significant improvement in our study. Hemodynamic results of the use of lipid emulsion in bupivacaine intoxication were better than the control group.

CONCLUSION: The SMOFlipid emulsion is a option for reversing hypotension in cases of intoxication by bupivacaine.

Key words: Anesthesia, Local. Bupivacaine. Lipids. Hemodynamics. Fat Emulsions, Intravenous. Swine.

\section{RESUMO}

OBJETIVO: Avaliar as alterações hemodinâmicas da terapia lipídica com SMOFlipid após intoxicação com bupivacaína em suínos.

MÉTODOS: Suínos da raça Large White foram anestesiados com tiopental, realizada intubação traqueal e mantidos em ventilação mecânica. As variáveis hemodinâmicas foram registradas através de pressão invasiva e cateterização da artéria pulmonar (cateter de Swan-Ganz). Após período de 30 minutos de repouso, $5 \mathrm{mg} \cdot \mathrm{kg}^{-1}$ de bupivacaína foram injetados por via endovenosa e novas medidas hemodinâmicas foram realizadas 1 minuto após; os animais foram então aleatoriamente divididos em dois grupos e receberam 4 ml.kg-1 de solução salina ou 4 ml. $\mathrm{kg}^{-1}$ da emulsão tipo SMOFlipid a 20\%. As alterações hemodinâmicas foram reavaliadas aos 5, 10, 15, 20 e 30 minutos.

RESULTADOS: A intoxicação pela bupivacaína causou queda da pressão arterial, índice cardíaco e do trabalho sistólico dos ventrículos principalmente sem importantes alterações das resistências vasculares. A terapia com a emulsão SMOFlipid foi capaz de melhorar a pressão arterial através, principalmente, do aumento das resistências vasculares uma vez que o índice cardíaco não apresentou melhora expressiva em nosso estudo. Os resultados hemodinâmicos com o uso da emulsão lipídica na intoxicação pela bupivacaína foram melhores que no grupo controle.

CONCLUSÃO: A emulsão SMOFlipid é uma opção para reverter a hipotensão em caso de intoxicação pela bupivacaína. Descritores: Anestesia Local. Bupivacaína. Lipídeos. Hemodinâmica. Emulsões Gordurosas Intravenosas. Suínos. 


\section{Introduction}

Locoregional anesthesia may require high doses of local anesthetics and there is always a potential risk of toxic reactions due to inadvertent intravascular injection. Bupivacaine is still the most widely used agent, owing to its good quality of anesthesia and prolonged duration of action ${ }^{1,2}$. However, in 1979, an editorial of Anesthesiology ${ }^{3}$ on the severe cardiovascular effects produced by accidental intravascular injections led to a search for new agents with lower toxicity and antidotes to combat their effects. Intravascular bupivacaine injection may result in severe toxicity of the central nervous and cardiovascular systems ${ }^{4}$ which are the main targets. Damage to the nervous system precedes cardiac compromise with signs and symptoms including tinnitus, metallic taste, visual disturbance, perioral numbness, loss of consciousness, convulsions and death. Cardiotoxicity is characterized by a decrease in ventricular contractility, loss of vasomotor tonus, cardiovascular collapse, arrhythmia and asystole ${ }^{5}$. Until 1981 the incidence of systemic toxicity was 100 per 10,000 epidural anesthesias $^{6}$; safety measures such as frequent aspiration before injection, use of a test dose and epinephrine began to be adopted in an attempt to reduce complications ${ }^{6}$. In a review study conducted in 1995 , Brown et al. $^{7}$ reported a rate of 1.2 complications per 10,000 epidural anesthesias, similar what was found by Auroy et $a l .{ }^{8}$ in France. New local anesthetics of long duration were synthetized and launched in the market such as ropivacaine and levobupivacaine which would be safer alternatives ${ }^{9}$. In 1998, Weinberg et $a l .{ }^{10}$ demonstrated that a lipid emulsion (LE) was efficient in the treatment of local anesthetic cardiotoxicity, increasing by $50 \%$ the mean lethal dose of bupivacaine, however these solutions had been used for parenteral nutrition since 1961! Rosenblatt et al. ${ }^{11}$ and later Litz et al. ${ }^{12}$ were the first to publish the successful use of LE in the treatment of cardiac arrest due to local anesthetics, when conventional resuscitative techniques had failed. There are now reports of the successful use of LE to treat toxicity due to these agents ${ }^{13,14}$. The aim of this study was to evaluate the hemodynamic changes after intravenous bupivacaine injection as a clinical scenario of toxicity and treatment with a $20 \%$ lipid solution named SMOFlipid ${ }^{15,16}$ (Soybean oil + Mediumchain triglycerides + Olive oil + Fish oil).

\section{Methods}

After approval from the Animal Experimentation Ethics Committee of the Biology Institute of UNICAMP, in compliance with the Council for International Organization of Medical Sciences (CIOMS) ethical code for animal experimentation, 20
Large-White pigs weighing between 19.5 and $23.5 \mathrm{~kg}$ were fasted overnight with free access to water. On the morning of the study the animals were weighed and body surface area was calculated by the formula ${ }^{17} \mathrm{BS}\left(\mathrm{m}^{2}\right)=\left(9 \mathrm{x}\right.$ weight in grams $\left.\mathrm{s}^{2 / 3}\right) \times 10^{-4}$ introducing the results on the Engstron $\mathrm{AS} / 3$ hemodynamic monitor for index calculation. Venipuncture was performed in the animal ear and anesthesia was induced with $2.5 \%$ sodium thiopental $25 \mathrm{mg} \cdot \mathrm{kg}^{-1}$. After intubation, the animals were maintained under controlled ventilation in a partial rebreathing system, tidal volume of 15 $\mathrm{ml} . \mathrm{kg}^{-1}$ and adequate respiratory rate to obtain $\mathrm{P}_{\mathrm{ET}} \mathrm{CO}_{2}$ between 32 and $34 \mathrm{mmHg}$. The pigs were ventilated with an air and $\mathrm{O}_{2}$ mixture maintaining hemoglobin saturation higher than 97\%, measured by a sensor placed on the tongue. A cardioscope was also used in DII lead. Isoflurane $1 \%$ expired fraction was used for maintenance of anesthesia. Local anesthesia with $5 \mathrm{ml}$ of $1 \%$ lidocaine without vasoconstrictor was administered to the internal portion of the pig thigh for dissection of the femoral artery and vein for continuous measurement of arterial blood pressure and introduction of the 7F Swan-Ganz catheter located in a branch of the pulmonary artery by the morphologic aspect of the pressure curve obtained. The following variables were measured: cardiac output, heart rate, mean arterial blood pressure, central venous pressure, mean pulmonary artery pressure and pulmonary capillary pressure. The monitor, using classical formulas calculated vascular resistances, ventricular work and all their indexes. After 30 minutes of stabilization and rest, baseline standard hemodynamic measurements were taken $\left(\mathrm{T}_{0}\right)$, followed by $5 \mathrm{mg} . \mathrm{kg} .{ }^{-1}$ of intravenous bupivacaine injection. One minute later, new hemodynamic measurements were taken $\left(\mathrm{T}_{1}\right)$. The animals were then randomly divided into two groups. In the first group $4 \mathrm{ml} \cdot \mathrm{kg}^{-1}$ of saline solution were injected immediately after $\mathrm{T}_{1}$ (CTRL group) and in the other $4 \mathrm{ml} \cdot \mathrm{kg}^{-1}$ of SMOFlipid (SMOF group) were $\square$ injected. New hemodynamic measurements were taken at 5, 10, 15, 20 and 30 minutes after toxicity $\left(\mathrm{T}_{5}\right.$ to $\left.\mathrm{T}_{30}\right)$. The numerical variables measured in a single time point were compared by the Student's t test. To study numerical variables in various time points Analysis of Variance for repeated measurements (ANOVA) was used, Duncan's test was used to compare the groups in each time point and the contrast profile test to analyze the progression between time points in each group. The significance level adopted was $5 \%(\mathrm{p}<0.05)$.

\section{Results}

Table 1 shows mean and standard deviations of weight and body surface areas. There were no statistic differences. 
TABLE 1 - Weigh and body surface area.

\begin{tabular}{ccc}
\hline Group & Weight \pm SD $(\mathbf{K g})$ & $\mathbf{B S A} \pm \mathbf{S D}\left(\mathbf{m}^{2}\right)$ \\
\hline CTRL & $21.15 \pm 1.29$ & $0.64 \pm 0.03$ \\
SMOF & $22.2 \pm 0.67$ & $0.66 \pm 0.01$ \\
\hline
\end{tabular}

$\mathrm{P}>0.05$

There were no differences in hemodynamic parameters at rest as well.

\section{Mean arterial blood pressure}

As shown in Figure 1, after bupivacaine injection there was a significant and similar decline in mean arterial pressure in both groups. Immediately following injection of the lipid, pressure increased in SMOF and remained higher than CTRL until the end $(\mathrm{p}<0.001)$. In CTRL, pressure increased progressively until 15 minutes. After this time and until the end of the experiment, values returned to levels similar to those in $\mathrm{T}_{0}(\mathrm{p}<0.001)$. In SMOF, pressures increased significantly in each time period until $\mathrm{T}_{15}$ and remained similar after that and always higher than at $\mathrm{T}_{\mathrm{o}}$.

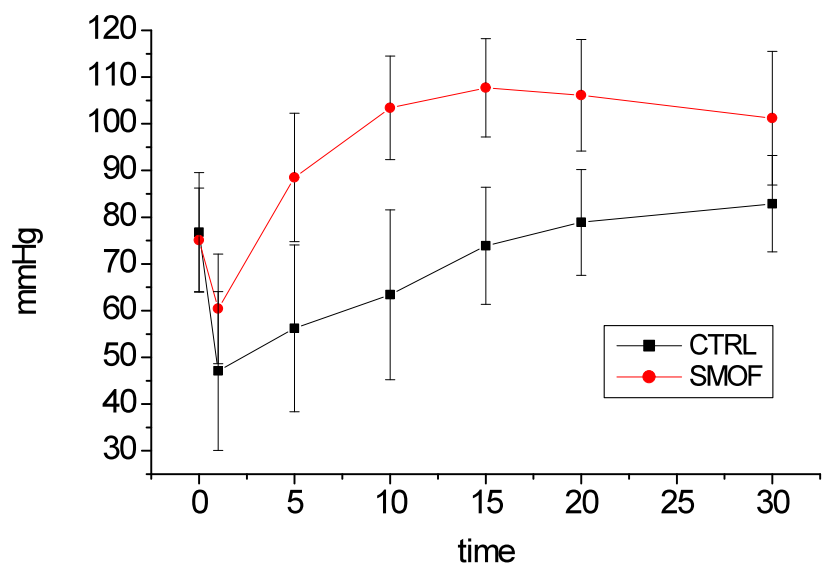

FIGURE 1 - Mean arterial pressure.

\section{Heart rate}

As shown in Figure 2 there was no changes in SMOF but the heart rate declined in CTRL and was lower than SMOF until $\mathrm{T}_{5}(\mathrm{p}=0.006)$. In CTRL values remained lower than $\mathrm{T}_{0}$ till the end but increased from $\mathrm{T}_{1}$ to $\mathrm{T}_{10}(\mathrm{p}=0.001)$.

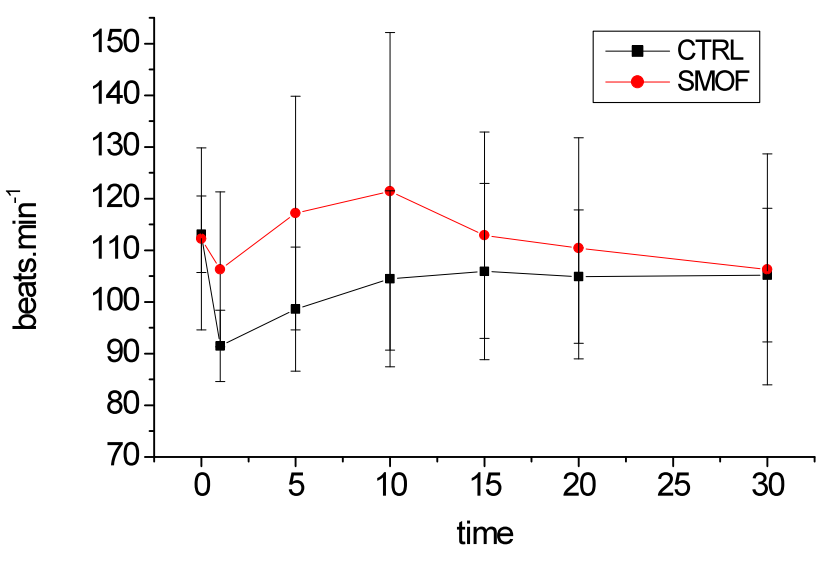

FIGURE 2 - Heart rate.

\section{Central venous pressure}

As seen in Figure 3, there was an increase in values in both groups, in SMOF they were higher than CTRL until $\mathrm{T}_{20}$ $(p<0.001)$. In both groups the results did not return to levels similar at rest until the end of the experiment, although in SMOF results were successively different from previous values $(p<0.001)$.

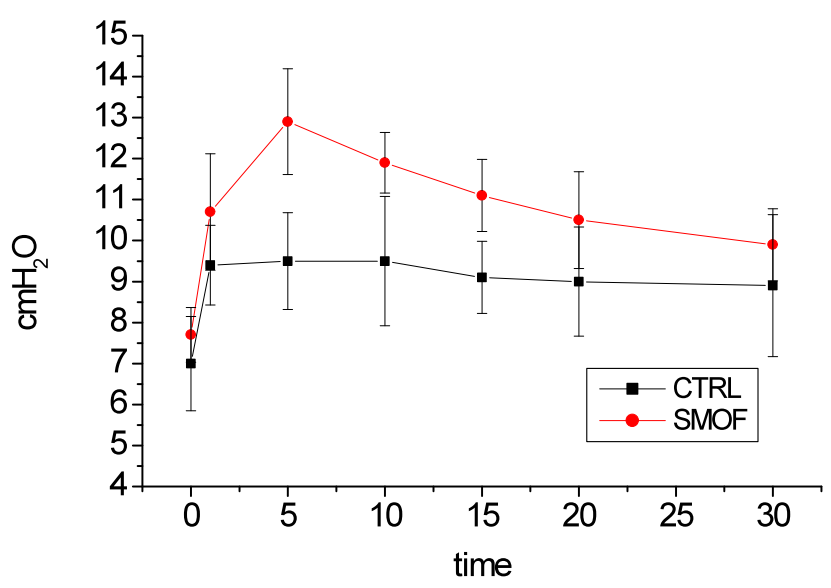

FIGURE 3 - Central venous pressure.

\section{Mean pulmonary artery pressure}

As observed in Figure 4, mean pulmonary artery pressure differed between groups after toxicity and until the end of the experiment $(p<0.001)$. In SMOF, it increased significantly and remained higher than rest till the end with differences between $\mathrm{T}_{1}$ and $\mathrm{T}_{5}$ in addition to $\mathrm{T}_{20}$ and $\mathrm{T}_{30}$. In CTRL, there were no differences relative to $\mathrm{T}_{0}(\mathrm{p}<0.001)$. 


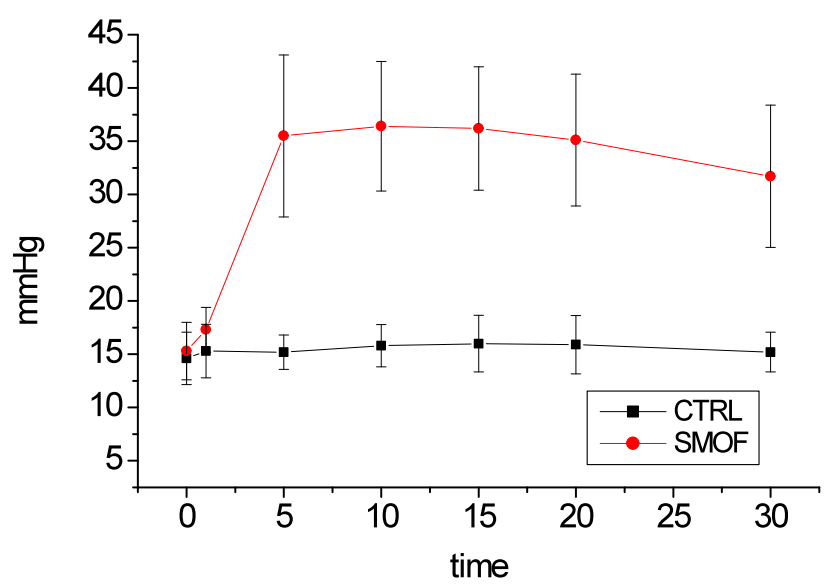

FIGURE 4 - Mean pulmonary arterial pressure.

\section{Pulmonary capillary wedge pressure}

As observed in Figure 5, in SMOF values were higher than CTRL from $\mathrm{T}_{1}$ to $\mathrm{T}_{15}(\mathrm{p}=0.002)$. In both groups, pressure values in all time periods were higher than in $\mathrm{T}_{0}$. However, in SMOF $T_{5}$ and $T_{15}$ were also higher than the values immediately prior to those time periods $(\mathrm{p}<0.001)$.

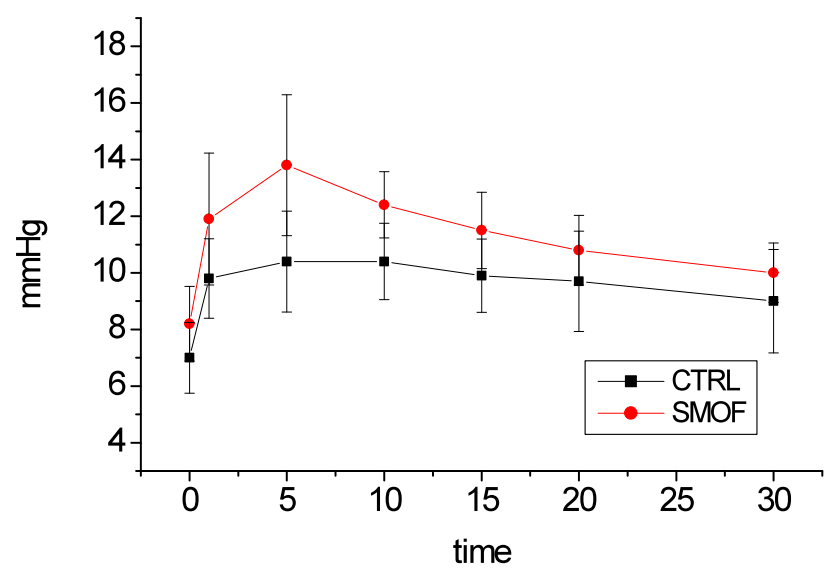

FIGURE 5 - Pulmonary capillary wedge pressure.

\section{Cardiac index}

As shown in Figure 6, the cardiac index decreased equally in both groups $(p=0.004)$. In CTRL values only returned to those similar to rest in $\mathrm{T}_{30}$ and $\mathrm{T}_{10}$ was lower than $\mathrm{T}_{15}$. In SMOF, values did not return to levels similar to $\mathrm{T}_{0}$, although they increased from $\mathrm{T}_{20}$ to $\mathrm{T}_{30}(\mathrm{p}<0.001)$.

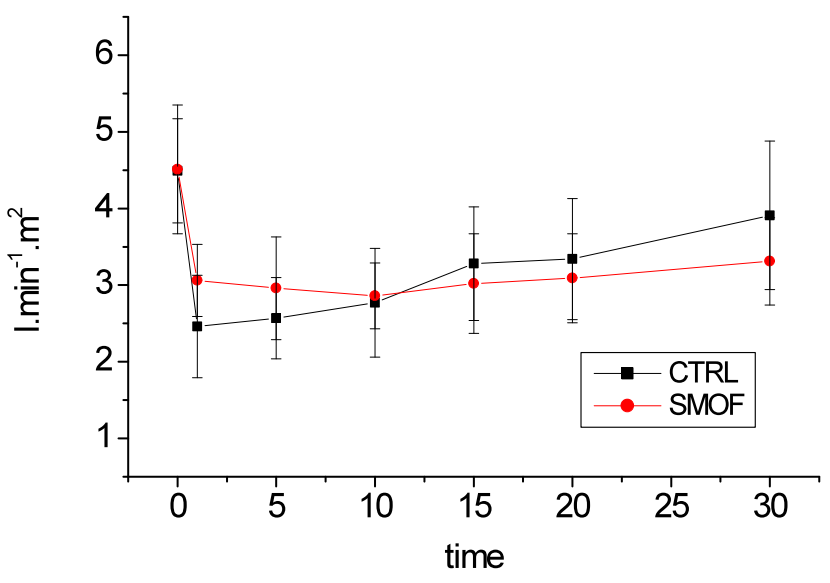

FIGURE 6 - Cardiac index.

\section{Systemic vascular resistance index}

As observed in Figure 7, the systemic vascular resistance index in SMOF was higher than in CTRL beginning at $\mathrm{T}_{5}$ till the end $(\mathrm{p}<0.001)$. In CTRL there was an increase from $\mathrm{T}_{10}$ to $\mathrm{T}_{30}$ and $\mathrm{T}_{1}$ was lower than $\mathrm{T}_{5}$. In SMOF all results were higher than $\mathrm{T}_{0}$ and exhibited significant increases in $\mathrm{T}_{5}, \mathrm{~T}_{10}$ and $\mathrm{T}_{30}$ compared to previous time $(\mathrm{p}<0.001)$.

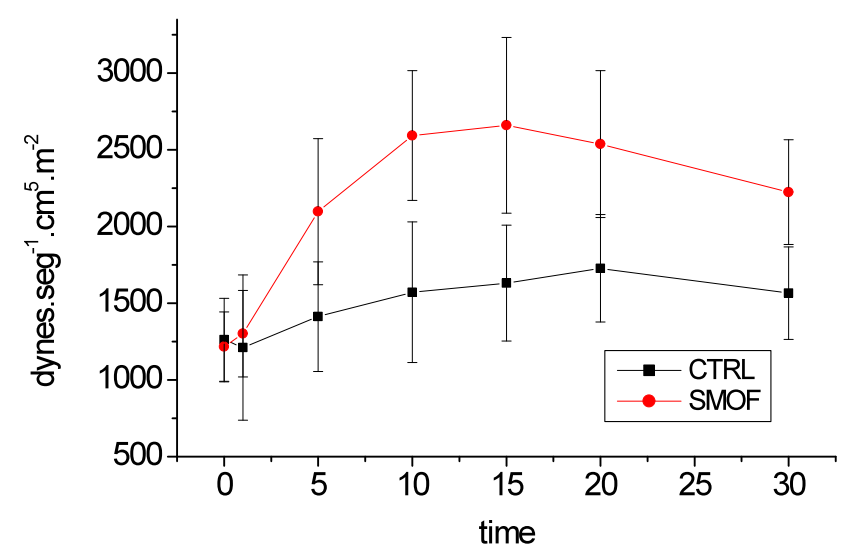

FIGURE 7 - Systemic vascular resistance index.

\section{Pulmonary vascular resistance index}

As shown in Figure 8, there was a significant increase in pulmonary vascular resistance in SMOF that remained higher than in CTRL from $\mathrm{T}_{5}$ to $\mathrm{T}_{30}(\mathrm{p}<0.001)$. In CTRL, there were no differences between time periods; in SMOF all values were higher than those at rest, $\mathrm{T}_{1}$ was lower than $\mathrm{T}_{5}$ and $\mathrm{T}_{20}$ higher than $\mathrm{T}_{30}$ $(\mathrm{p}<0.001)$. 


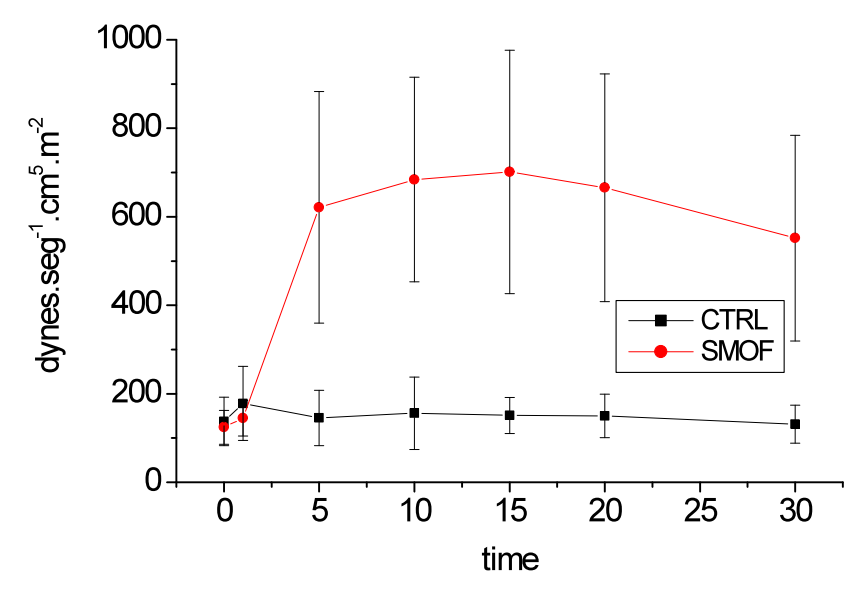

FIGURE 8 - Pulmonary vascular resistance index.

\section{Left ventricular systolic work index}

As observed in Figure 9, left ventricle systolic work index had a significant decline in both groups and this was more striking in CTRL until $\mathrm{T}_{15}(\mathrm{p}=0.049)$. In CTRL all values remained lower than standard levels until $\mathrm{T}_{20}$ and $\mathrm{T}_{15}$ and $\mathrm{T}_{30}$ were higher than the previous values; in SMOF there was a progressive increase in $\mathrm{T}_{5}$, $\mathrm{T}_{10}$ and $\mathrm{T}_{20}$ when values returned to similar at rest $(\mathrm{p}<0.001)$.

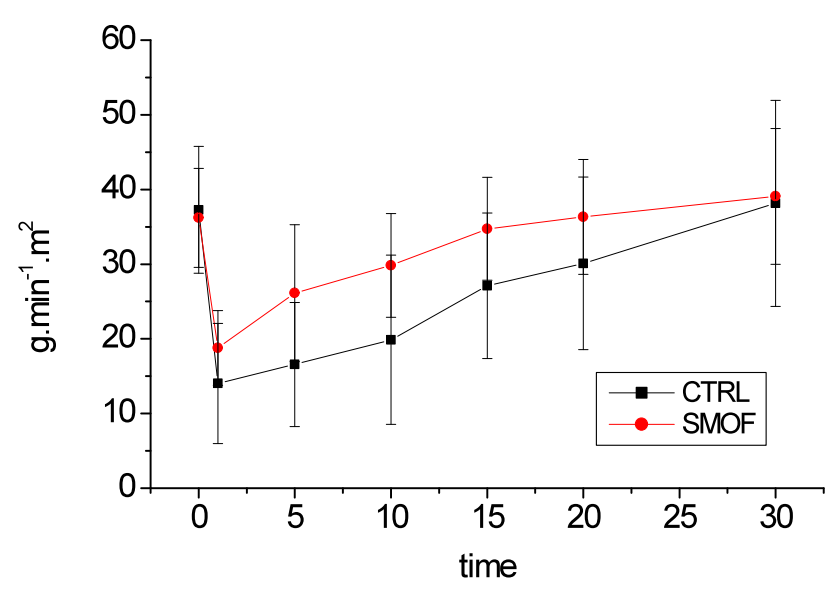

FIGURE 9 - Left ventricular stroke work index.

\section{Right ventricular systolic work index}

As observed in Figure 10, the right ventricular systolic work index had a significant decrease in both groups, however, in SMOF values recovered and remained higher then CTRL from $\mathrm{T}_{5}$ till the end $(\mathrm{p}<0.001)$. In CTRL, values returned to those similar to rest in $\mathrm{T}_{15}$ and remained constant until the end. In SMOF, after $\mathrm{T}_{5}$ and until the end these values were higher than those at rest $(\mathrm{P}<0.001)$.

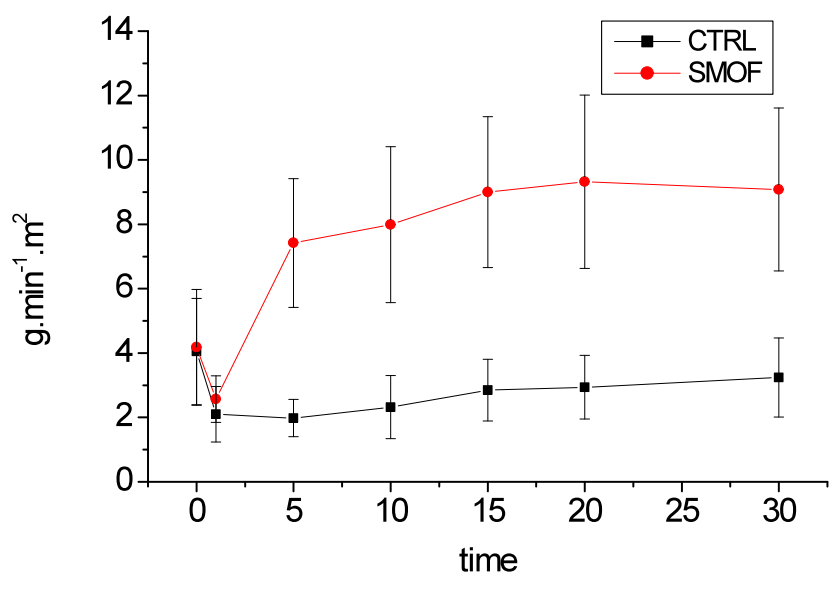

FIGURE 10 - Right ventricular stroke work index..

\section{Discussion}

Cardiotoxicity of local anesthetics is still a concern for anesthesiologists. Until recently, it was a devastating complication without any specific treatment. Since 2006, with a publication on the successful use of lipid emulsion ${ }^{11,12}$ to treat cardiotoxicity due to intravascular injection of local anesthetics, several formulations have been suggested for this purpose ${ }^{13}$. We chose to use the $20 \%$ SMOFlipid solution because there are few cases describing its use for this type of complication. Three hypotheses on the mechanism of action of lipids in local anesthetic toxicity have been formulated. The first theory, known as 'lipid sink', suggests the establishment of new pharmacokinetics, with expansion of the lipemic phase that would sequester local anesthetic molecules, decreasing the free fraction and consequently toxicity of these agents ${ }^{18}$. This is a well-accepted theory since it was observed that toxicity of other lipophilic drugs, as some antipsychotics, barbiturates, antidepressants, organophosphates and antihypertensives, also responds to a lipid infusion. In corroboration with this theory, Turner-Laurence and Kerns demonstrated in vitro the binding capacity of lipid emulsions to local anesthetics in buffer solutions ${ }^{19}$. In the plasma, bupivacaine binds to alfa-1 glycoprotein and albumin. The affinity for alfa-1 is greater than that for albumin, although albumin is more abundant. The binding capacity of lipid emulsions to bupivacaine is important, a $1 \%$ solution is equivalent to 1.5 to 4 times the binding capacity of human plasma. Thus 100 $\mathrm{ml}$ of a $20 \%$ lipid emulsion would have the same binding capacity to albumin contained in 7 to 12 liters of plasma ${ }^{20}$. The second theory states that lipid emulsions would overcome by mass effect, or by some other unknown mechanism, bupivacaine inhibition of carnitine-acetyltransferase. This enzyme is essential for fatty acid transportation into the mitochondria where they are used 
as substrate for energy production by the myocardium and other tissues $^{21}$. And finally, the third theory states that an increase in fatty acids would increase the calcium levels in cardiac myocytes, promoting a positive inotropic effect ${ }^{22}$. In our study, we observed a rapid and significant improvement in arterial blood pressure in animals treated with SMOFlipid after local anesthetic toxicity. We can infer that the reasons for this improvement may be an extraction of bupivacaine molecules by the lipid emulsion and an increase in the systemic and pulmonary vascular resistance indexes, since we did not observe great changes in cardiac index. In 2011, Ok et al. ${ }^{23}$ published the first study demonstrating that LE reverses vasodilation caused by local anesthetics in the isolated rat aorta, they suggested that the mechanism of this reversal may be blunting of inhibition mediated by local anesthetics in the calcium voltage-dependent channels in smooth vascular muscles and partially by endothelial release of nitric oxide ${ }^{23}$. It is worth noting that, if the reason for restoration of arterial blood pressure was only an increase in vascular resistance and the lipid emulsion did not exert this type of influence, the same results should have been achieved when vasoconstrictors were used. However, cardiac arrest due to this type of complication is often resistant to adrenergic therapy and may even lead to severe pulmonary edema after the use of epinephrine ${ }^{24}$. Weinberg studied cardiac arrest caused by bupivacaine toxicity in rats. The same author reported better results when LE rather than epinephrine was used for treatment ${ }^{25}$. Concerning the heart rate, in SMOF it was more stable than CTRL, a result similar to that found by Chen et al. ${ }^{26}$. We also observed a significant increase in pulmonary artery pressure in SMOF compared to CTRL. This alteration was described as one of the side effects of LE when a dose higher than $100 \mathrm{mg} \cdot \mathrm{kg}^{-1} \cdot \mathrm{h}$ was used or when LE was given to patients with previous pulmonary disease $^{27}$. Finally, other side effects of lipid emulsions have been described: risk of infection, allergic reactions especially in soy oil emulsions, thrombophlebitis, increased amylase, hyperlipidemia, hemolytic anemia, thrombocytopenia and fat embolus ${ }^{19}$.

\section{Conclusion}

The SMOFlipid emulsion proved to be efficient in the reversal of hemodynamic alterations due to bupivacaine toxicity in pigs, suggesting that the early use of this lipid solution may help to prevent or mitigate the cardiotoxicity of local anesthetics.

\section{References}

1. Groban L, Deal DD, Vernon JC, James RL, Butterworth J.
Cardiac resuscitation after incremental overdosage with lidocaine, bupivacaine, levobupivacaine and ropivacaine in anesthetized dogs. Anesth Analg. 2001;92(1):37-43.

2. Chang DH, Ladd LA, Copeland S, Iglesias MA, Plummer JL, Mather LE. Direct cardiac effects of intracoronary bupivacaine, levobupivacaine and ropivacaine in the sheep. Br J Pharmacol. 2001;132(3):649-58.

3. Albright GA. Cardiac arrest following regional anesthesia with etidocaine or bupivacaine. Anesthesiology. 1979;51(4):285-7.

4. Melo MSD, Silva WA, Moraes AC, Udelsmann A. Comparison of hemodynamic changes in acute intoxication with intravenous bupivacaine and ropivacaine in swine. Rev Bras Anestesiol. 2009;59(5):592-601.

5. Leone S, Cianni SD, Casati A, Fanelli G. Pharmacology, toxicology, and clinical use of new long acting long anesthetics, ropivacaine and levopubivacaine. Acta Biomed. 2008;79(2):92-105.

6. Mulroy MF. Systemic toxicity and cardiotoxicity from local anesthetics: incidence and preventive measures. Reg Anesth Pain Med. 2002;27(6):556-61.

7. Brown DL, Ransom DM, Hall JA, Schroeder DR, Offord KP. Regional anesthesia and local anesthetic-induced systemic toxicity: seizure frequency and accompanying cardiovascular changes. Anesth Analg. 1995;81(2):321-8.

8. Auroy Y, Narchi P, Messiah A, Litt L, Rouvier B, Samii K. Serious complications related to regional anesthesia: results of a prospective survey in France. Anesthesiology. 1997;87(3):479-86.

9. Heavner JE. Local anesthetics. Cur Opin Anaesthesiol. 2007;20(4):336-412.

10. Groban L, Butterworth J. Lipid reversal of bupivacaine toxicity: has the silver bullet been identified? Reg Anesth Pain Med. 2003;28(3):167-9.

11. Rosenblatt MA, Abel M, Fischer GW, Itzkovich CJ, Eisenkraft JB. Successful use of a $20 \%$ lipid emulsion to resuscitate after a presumed bupivacaine-related cardiac arrest. Anesthesiology. 2006;105(1):217-8.

12. Litz RJ, Popp M, Stehr Sn, Koch T. Successful resuscitation of a patient with ropivacaine-induced asystole after axilary plexus block using lipid emulsion. Anaesthesia. 2006;61(8):800-1.

13. Warren JA, Thoma RB, Georgescu A, Shah SJ. Intravenous lipid infusion in the successful resuscitation of local anesthetic-induced cardiovascular collapse after supraclavicular brachial plexus block. Anesth Analg. 2008;106(5):1578-80.

14. Dix SK, Rosner GF, Nayar M, Harris JJ, Guglin ME, Winterfield JR, Xiong Z, Mudge GH Jr. Intractable cardiac arrest due to lidocaine toxicity successfully resuscitated with lipid emulsion. Crit Care Med. 2011;39(4):872-4.

15. Schlotzer E, Kanning U. Elimination and tolerance of a new parenteral lipid emulsion (SMOF)--a double-blind cross-over study in healthy male volunteers. Ann Nutr Metab. 2004;48(4):263-8.

16. Mertes N, Grimm H, Furst P, Stehle P. Safety and efficacy of a new parenteral lipid emulsion (SMOFlipid) in surgical patients: a randomized, double-blind, multicenter study. Ann Nutr Metab. 2006;50(3):253-9.

17. Holt JP, Rhode EA, Kines H. Ventricular volumes and body weigh in mammals. Am J Physiol. 1968;215(3):704-15.

18. Aya AG, Ripart J, Sebbane MA, de La Coussaye JE. Lipid emulsions for the treatment of systemic local anesthetic toxicity: efficacy and limits. Ann Fr Anesth Reanim. 2010;29(6):464-9.

19. Turner-Laurence DE, Kerns li W. Intravenous fat emulsion: a potential novel antidote. J Med Toxicol. 2008;4(2):109-14.

20. Mazoit JX, Le Guen R, Beloeil H, Benhamou D. Binding of long-lasting local anesthethics to lipid emulsions. Anestesiology. 2009;110(2):380-6. 
21. Mazoit JX, Cao LS, Samii K. Binding of bupivacaine to human serum proteins, isolated albumin and isolated alpha-1-acid glycoprotein. Differences between the two enantiometers are partly due to cooperatively. J Pharmacol Exp Ther. 1996;276(1):109-15.

22. Cave G, Harvey M. Intravenous lipid emulsion as antidote beyond local anesthetic toxicity: a systematic review. Acad Emerg Med. 2009;16(9):815-24.

23. Ok SH, Sohn JT, Baik JS, Kim JG, Park SS, Sung HJ, Shin MK, Kwon YH, Park CS, Shin IW, Lee HK, Chung YK. Lipid emulsion reverses levobupivacaine-induced responses in isolated rat aortic vessels. Anestesiology. 2011;114(2):293-301.

24. Leskiw U, Weinberg G. Lipid resuscitation for local anesthetic toxicity: is it realy life saving? Cur Opin Anaesthesiol. 2009;22(5):667-71.

25. Weinberg GL, Di Gregorio G, Ripper R, Kelly K, Massad M, Edelman L, Schwartz D, Shah N, Zheng S, Feinstein DL. Resuscitation with lipid versus epinephrine in a rat model of bupivacaine overdose. Anesthesiology. 2008;108(5):907-13.

26. Chen Y, Xia Y, Liu L, Shi T, Shi K, Wang Q, Chen L, Papadimos $\mathrm{TJ}, \mathrm{Xu} \mathrm{X}$. Lipid emulsion reverses bupivacaine-induced asystole in isolated rat hearts. Anesthesiology. 2010;113(6):1320-5.

27. Brull SJ. Lipid emulsion for treatment of local anesthetic toxicity: patient safety implications. Anesth Analg. 2008;106(5):1337-9

\section{Correspondence:}

Artur Udelsmann

Avenida Professor Atílio Martini, 213

13083-830 Campinas - SP Brasil

audelsmann@yahoo.com.br

Received: November 17, 2011

Review: January 18, 2012

Accepted: February 15, 2012

Conflict of interest: none

Financial source: none

${ }^{1}$ Research performed at the Laboratory of Experimental Anesthesia, State University of Campinas (UNICAMP), Sao Paulo, Brazil. 